nasalward and temporalward motion are asymmetric in early but not late onset strabismus. Invest Ophthalmol Vis Sci 1990; 31: 289

4 Mitsui T, Tamura O, Berard OV, Reddy R. Optomotor effects in esotropia under general anesthesia. In: Strabismus II, Proceedings IV International Strabismus Association. New York: Grune and Stratton, 1982; 429-38.

5 Norcia AM, Humphrey R, Garcia H, Holmes A. Anomalous motion VEPs in infants and in infantile esotropia. Invest Ophthalmol Vis Sci 1989; 30: 327

6 Quick MW, Tigges M, Gammon JA, Boothe RG. Early abnormal visual experience induces strabismus in infant monkeys. Invest Ophthalmol Vis Sci 1989; 30: 1012-7.

7 Tychsen L, Lisberger SG. Maldevelopment of visual motor processing in humans who had strabismus with onset in infancy. 7 Neurosci 1986; 6: 2495-508.

8 Tychsen L, Hurtig RG, Scott WE. Pursuit is impaired but the vestibulo-ocular reflex is normal in infantile strabismus. Arch Ophthalmol 1985; 103: 536-9.

9 Tychsen L, Quick M, Boothe RG. Alternating monocular input from birth causes stereoblindness, motion processing asymmetries, and strabismus in causes stereoblindness, motion processing asymmetries,

10 Keiner GBJ. New viewpoints on the origin of squint: a clinical and statistical study on its nature, cause, and therapy. The Hague: Martinus Nijhoff, 1951.
11 Jampolsky A. Unequal visual inputs and strabismus management: a comparison of human and animal strabismus. Trans New Orleans Acad parison of human and animal strabismus.

12 Atkinson J. Development of optokinetic nystagmus in the human infant and monkey infant: an analogue to development in kittens. In: Freeman RD, ed. Developmental neurobiology of vision. New York: Plenum, 1979: 2277-87.

13 Tychsen L. Motion sensitivity and the origins of infantile vision. In: Simons K ed. Early visual development, normal and abnormal. New York: Oxford University Press, 1993: 364-87.

14 Judge SJ, Cumming BG. Neurons in the monkey midbrain with activity related to vergence eye movement and accommodation. 7 Neurophysiol 1986; 55: to vergence.

15 Mays LE, Porter JD, Gamlin PDR, Tello CA. Neural control of vergence eye movements: neurons encoding vergence velocity. $\mathcal{F}$ Neurophysiol 1986; 56 1007-21.

16 Duane A. A new classification of motor anomalies of the eye. Philadelphia: J B Lippincott, 1897.

17 Good WV, De Sa L, Lyons CI, Hoyt CS. Monocular visual outcome in untreated early onset esotropia. Br f Ophthalmol 1993; 77: 492-5.

\title{
What is the use of ocular blood flow measurement?
}

We may be impressed or otherwise by the nomenclature of methods of haemodynamic measurements of the eye such as ophthalmodynamography, oculo-oscillodynamography, pneumoplethysmography, bidirectional laser Doppler velocimetry (BLDV), or blue field entoptoscopy and be tempted to interpret the importance of the results as inversely proportional to the complexity of the name. The article by Fujio et $a l$, in this issue of the journal, in which BLDV is employed to investigate the effect of panretinal photocoagulation on retinal blood flow, provides an opportunity to reconsider the relevance or not of blood flow investigations to the understanding of disease processes and to the formulation of clinical practice.

When any method is employed to investigate physiological properties and particularly where technology is involved it is important to remember two possible areas of contention. Firstly, what assumptions have been made to allow the calculation of the parameters? Without going into detail on a particular method, there are assumptions, often multiple, which have been made with each method that is used - for example, in this article Fujio et al rightly inform us that an assumption is made, during the calculation of blood flow, that the cross sectional area of a retinal vessel is circular. Such action is unavoidable in most blood flow measurements in clinical investigation because there are large gaps in our knowledge of in vivo ocular vessel dimensions and other circulatory properties. It is nevertheless important for the investigators (as in this article) to provide a means of accessing such information and for the reader to interpret the results accordingly.

This leads us to the second point for consideration namely, interpretation. There is no technique available which provides direct measurement of blood flow in the eye. Doppler (ultrasound or laser) measures blood cell velocities, ${ }^{12}$ tonography techniques measure 'pulsatile blood flow', ${ }^{34}$ ocular compression techniques measure blood pressure, ${ }^{5}$ videoangiography records dye bolus velocities, ${ }^{67}$ and blue field entoptoscopy provides white cell velocities. ${ }^{8}$ Extrapolation of results to retinal blood flow requires vessel diametric measurements (impossible in other orbital vessels for example, in the posterior ciliary circulation) which then involve more assumptions and can at best only allow estimations of the actual blood flow. It is, therefore, often difficult to know how to interpret the results of studies - for example, what is the relation of 'pulsatile blood flow' to total blood flow? An informed interpretation of the available methods is required, perhaps backed up by the knowledge obtained from studies of animal models (the methodologies of which should be more controllable).

The limitations in techniques of measurement of actual blood flow do not prevent their application in the clinical setting - for example, Fujio et al have suggested that BLDV could be used to predict the response to laser therapy and colour Doppler imaging has been used to detect retinal ischaemia in central retinal vein occlusion. ${ }^{910} \mathrm{~W}$ ith this aim absolute blood flow measurement is not required, we need only look at the use of fluorescein angiography to see the application of an imperfect measure of blood flow to the clinical setting.

The complexity of the multiple influences on blood flow in the human means that it will be a long time before we fully understand the interaction of these influences in the normal individual, let alone in disease. The fact remains, however, that in a vascular organ such as the eye, where vascular mishap is commonplace, we cannot afford to ignore the information which these methods provide.

Tennent Institute of Ophthalmology,

TOM H WILLIAMSON

Western Infirmary,

1 Baxter GM, Williamson TH, McKillop G, Dutton GN. Color Doppler ultrasound of orbital and optic nerve blood flow: effects of posture and timolol ultrasound of orbital and optic nerve blood flow: effect

2 Riva CE, Grunwald JE, Sinclair SH, Petrig BL. Blood velocity and volumetric flow rate in human retinal vessels. Invest Ophthalmol Vis Sci 1989; 30: $1124-32$.

3 Silver DM, Farrell RA, Langham ME, O'Brien V, Schilder P. Estimation of pulsatile ocular blood flow from intraocular pressure. Acta Ophthalmol (Copenh) 1989; 191 (suppl): 25-9.

4 Langham ME, Farrell RA, O'Brien V, Silver DM, Schilder P. Blood flow in the human eye. Acta Ophthalmol (Copenh) 1989; 191 (suppl): 9-13.

5 Ulrich WD, Ulrich C. Oculo-oscillo-dynamography: a diagnostic procedure for recording ocular pulses and measuring retinal and ciliary arterial blood pressures. Ophthalmic Res 1985; 17: 308-17.

6 Hickam JB, Frayser R. A photographic method for measuring the mean retinal circulation time using fluorescein. Invest Ophthalmol Vis Sci 1965; 4: 876-84.

Korber N. Measurement of retinal blood flow in various patholocical conditions by video fluorescence angiography. Klin Wochenschr 1986; 64: 950-3.

8 Riva CE, Petrig B. Blue field entoptic phenomenon and blood velocity in the retinal capillaries. F Opt Soc Am 1980; 70: 1234-8.

9 Williamson TH, Baxter GM. Retinal blood flow measurement by color Doppler imaging in patients with central retinal vein occlusion. Invest Ophthalmol Vis Sci 1993; 34 (suppl): 841 .

10 Baxter GM, Williamson TH. Color flow imaging in central retinal vein occlusion: a new diagnostic technique? Radiology 1993; 187: 847-50. 